The solution to be precipitated is poured into the flask, this in turn corked up, and the apparatus stood in the hood. The gas is now passed into the solution and the flask violently shaken by hand. The bends in the exit tube keep any of the solution from being thrown out of the flask. The churning up of the solution with the hydrogen sulphide gas quickly throws out of solutions the metals of the copper-arsenic group.

The young men tell me that not only is the time necessary for complete precipitation greatly shortened but the sulphides are obtained in a form more easily filtered and washed, by the use of this apparatus.

EAston, PA., January 19, I899.

\title{
ACTION OF A HARD WATER ON CERTAIN METALS.
}

BY JAS. LEWIS Howe AND J. I. MORRISON.

Received February 25, 1899 .

THE work described in this paper was undertaken for the purpose of studying the action of the town water supply of Lexington, $\mathrm{Va}$., on brass, as complaint had been made by plumbers and others that brass faucets, valves, etc., were rapidly corroded by the water and rendered useless.

An analysis of the water furnished me by Col. N. B. Tucker, of the Virginia Military Institute, is as follows .

\begin{tabular}{|c|c|}
\hline \multirow{2}{*}{\multicolumn{2}{|c|}{$\begin{array}{l}\text { Parts per } 1 \\
\end{array}$}} \\
\hline & 7.30 \\
\hline Magnesia .............. & 4.065 \\
\hline Ferrous oxide .... & 0.2057 \\
\hline Soda $\ldots . . . . . . . .$. & 0.3608 \\
\hline Carbon dioxide......... & $30.19^{6}$ \\
\hline Sulphur trioxide........ & 0.2127 \\
\hline silica $\ldots \ldots \ldots \ldots \ldots$ & 0.730 \\
\hline Chlorine $\ldots \ldots \ldots \ldots \ldots \ldots \ldots$ & trace \\
\hline Potash $\ldots \ldots \ldots \ldots \ldots \ldots \ldots \ldots$ & absent \\
\hline
\end{tabular}

The relatively high proportion of magnesia is due to the fact that most of the limestone of the region is highly magnesian. Several different metals were tested and in each case a duplicate was made with distilled water. The method used was as follows: The metals were in thin strips except the brass which was in the form of wire. The surface was thoroughly cleaned with emery paper, the metal weighed, and the area of exposed 
surface measured. With each metal two bottles of about a half-liter capacity and two open jars holding about two liters were used. One of the bottles was filled with town water and the other with distilled water and tightly corked, care being taken that no air should be in the bottle. One jar was filled with town water, the other with distilled water and left open to the air with a slight protection from dust. As the water evaporated more water was added. The temperature ranged from $10^{\circ}$ to $20^{\circ}$, or occasionally perhaps $25^{\circ}$. After four months the metals were removed, and, after brushing off any loosely adhering deposit, weighed. The water was tested qualitatively for the presence of the metal in solution. The amounts of metal used in each case and the surface were approximately as follows: Brass, 36 grams, IO5 sq. cm. ; zinc, 56 grams, I $70 \mathrm{sq}$. cm.; copper, I7 grams, 243 sq. cm.; iron, 64 grams, 39 I sq. cm.; lead, 375 grams, $500 \mathrm{sq}$. cm.; aluminum (thin commercial sheet), I.6 grams, I 75 sq. cm.

In a further experiment a bundle of brass wire was packed in the pipes behind two of the laboratory faucets. One of these faucets (A) was used almost constantly all day, the other (B) perhaps half as much. These wires weighed respectively 36.540 and 36.527 grams and presented each ro5.5 sq. cm. surface; these were left in position three and one-half months.

The results are expressed in the following table in terms of milligrams per square centimeter of surface :

BRASS.

Loss or gain

in weight.

Town water, closed bottle,

" " open jar,

0.047 loss

Distilled water, closed bottle,

" " open jar,

0.019 gain

Faucet $\mathbf{A}$,

$3 \cdot 742$ loss

$\because B$

I. 108 “
Surface bright; no copper or zinc in water.

Surface bright, except at ends of wires; no copper but much zinc in water.

Surface bright ; no copper or zinc in water.

Surface bright except at ends of wires; no copper or zinc in water.

Surface showed much tarnish Surface showed much tarnish 
Zixc.

Loss or gain

in weight.

Town water, closed bottle, $\quad$ I.54 gain

$$
\text { " " open jar, }
$$

2.523

Distilled water, closed bottle, 0.348 “

" " open jar,

0.1165

COPPER.

Town water, closed bottle,

0

" " opeu jar,

0.16 loss

Distilled water, closed bottle, o

" " open jar,

0.131 gain

IRON.

Town water, closed bottle, 0.025 loss

" " open jar,

6.966 "

Distilled water, closed bottle, 0.077 "

$$
\text { open jar, } \quad 7.086 \text { “ }
$$

LEAD.

Town water, closed bottle, " " open jar,

I. 304 loss

I. 152 "

Distilled water, closed bottle, 2.306 " " " open jar, 3.39r"

Aluminum.

Town water, closed bottle,

$$
\text { " " open jar, }
$$

Distilled water, closed bottle, 0

" “ open jar,

0.I 28 loss
Surface slightly oxidized; zinc in water.

Surface much oxidized; much zinc in water.

Surface slightly oxidized; trace of zinc in water.

Surface slightly oxidized; trace of zinc in water.

Surface bright; slight trace of copper in water.

Surface tarnished, copper in water.

Surface bright; trace of copper in water.

Surface tarnished, red to black; copper in water.

Surface slightly rusted; iron in water; 0.15 gram deposit.

Much rust; irou in water; 4.575 gram deposit.

Surface taruished; iron in water; 0.085 gram deposit.

Much rust; iron in water; 4.965 grams deposit.

Surface bright; lead in water. Surface somewhat tarnished; little lead in water.

Surface bright; lead in water.

Surface much tarnished; much lead in water.

Surface bright; noaluminum in water.

Surface bright; no aluminum in water.

Surface bright; noaluminum in water.

Surface much taruished; aluminum in water. 
This table reveals several points regarding the action on metals of a hard water containing an excess of carbon dioxide with considerable magnesia, and little sulphate and no chlorine.

I. Such a water acts readily upon zinc, far more readily than does distilled water, and it seems to be able to dissolve out the zinc in brass, leaving the brass much corroded. This would explain the action of the water on brass faucets, etc., above mentioned. Such a water should not be conveyed through zinc-lined iron pipes.

2. The hardness of such a water is no protection against its action on lead, this water having more than half as wuch action as distilled water when protected from the air.

3. Protected from the air, the action upon iron is comparatively slight.

4. Aluminum is perfectly resistant against a water of this character.

Similar experiments were carried out with nickel, but in no case did the water have any action upon it.

WASHINGTON AND LEE UNIVERSITY,

LEXINGTON, VA.

\section{NOTES ON THE ANALYSIS OF DYNAMITE AND GELATINE- DYNAMITE.}

BY F, W. SMITH,

Received January 19,1899 .

I.

THE analysis of dynamite is not often described in text-books and the following notes, gleaned from some years' experience, may be of interest to those who have occasion to investigate such products.

A simple case is that of a dynamite containing nitroglycerine, sodium nitrate, wood-pulp, and basic magnesium carbonate or kieselguhr. The following process of analysis is recommended as giving satisfactory results. Weigh out ten grams on a pair of watch-glasses, place in a desiccator over sulphuric acid and leave for at least five days. The loss in weight is called moisture. Weigh about the same amount into a Gooch crucible and extract with pure ether. A drop of the ether is allowed to evaporate on a piece of tissue paper from time to time, and the extraction continued until the paper no longer tastes of nitroglycerine. Dry the residue in an air-bath at about $80^{\circ} \mathrm{C}$. for two to three hours 